\begin{tabular}{|c|c|c|c|c|c|c|}
\hline \multirow{4}{*}{ Impact Factor: } & ISRA (India) & $=3.117$ & SIS (USA) & $=0.912$ & ICV (Poland) & $=6.630$ \\
\hline & ISI (Dubai, UAI & $=0.829$ & РИНЦ (Russia) & $=0.156$ & PIF (India) & $=1.940$ \\
\hline & GIF (Australia) & $=0.564$ & ESJI (KZ) & $=8.716$ & IBI (India) & $=4.260$ \\
\hline & JIF & $=1.500$ & SJIF (Morocco & $=5.667$ & OAJI (USA) & $=0.350$ \\
\hline
\end{tabular}

\section{SOI: $1.1 /$ TAS DOI: $10.15863 /$ TAS International Scientific Journal Theoretical \& Applied Science}

\author{
p-ISSN: 2308-4944 (print) e-ISSN: 2409-0085 (online) \\ Year: 2019 Issue: $05 \quad$ Volume: 73
}

Published: $21.05 .2019 \quad \underline{\text { http://T-Science.org }}$
QR - Issue

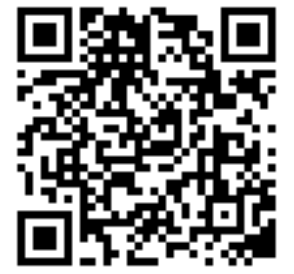

QR - Article

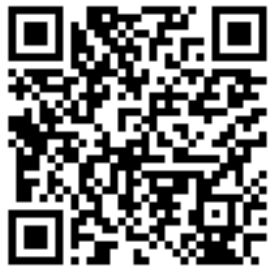

Mavjuda Ergashevna Suyarova Senior lecturer, English language teacher

Zukhra Allaberdievna Zulfiqorova English language teacher; Department of Foriegn languages Karshi Engineering-Economic institute

\title{
TEXT ANALYSIS IN TECHNICAL ENGLISH
}

Abstract: In teaching ESP courses, words play crucial role in text analysis; collocations, concordances, types and tokens, frequency-words occurring in technical language. Even single word gives a written context broad meaning. In this study, we conducted a research on the issues of constructing words such as; single words, collocations, and frequency-words occur in petroleum engineering context. In the classes of English for specific purposes, we mostly focused on technical words related to the field of petroleum engineering because there are some tokens and types which students of engineering need to acquire in order to use them in target environment both in written and oral forms. This paper highlights discussions of scholars on the issues of corpus linguistics, especially, analysis of collocations, tokens and types occurring in written context.

Key words: collocations, frequency words, written context.

Language: English

Citation: Suyarova, M. E., \& Zulfiqorova, Z. A. (2019). Text Analysis in Technical English. ISJ Theoretical \& Applied Science, 05 (73), 126-128.

Soi: http://s-o-i.org/1.1/TAS-05-73-21 Doi: crossef https://dx.doi.org/10.15863/TAS.2019.05.73.21

\section{Introduction}

Recent developments in the study of lexis have generated new applications within lexicography and language teaching, offering the possibility of a better understanding of the nature of the lexicon, especially multi-word phenomena. Besides, the notion of collocation shifts the emphasis from the single word to pairs of words as integrated chunks of meaning in the contexts, and collocation has become an uncontroversial element in a good deal of language description and pedagogy. Languages are full of strong collocational pairs and, therefore, collocation deserves to be a central aspect of vocabulary study. Knowledge of collocational appropriacy is part of the native speaker's competence, and can be problematic for learners in cases where collocability is language specific and does not seem solely determined by universal semantic constraints. Even very advanced learners often make inappropriate or unacceptable collocations. Even advanced learners often make inappropriate or unacceptable collocations, and knowledge of collocation is knowledge of what words are most likely to occur together (6:12-14)

Moreover, there are some tokens and types, frequent words occurring in the context of specialty, those are more needful to acquire and use in target environment. Present study shows text analysis, indicating of discussion; collocations, corpora, and tokens and types occurring in the contexts of petroleum engineering in Russian language.

\section{Collocation in English language context}

The collocational dimension of the mental lexicon has been increasingly seen as playing a vital role in respect of both $\mathrm{L} 1$ acquisition and FL acquisition (2). Collocations (e.g., make a mistake; tell the truth; take a photo; running water; narrow escape; sore throat; wide awake; deeply religious; at school; on purpose), along with other kinds of multiword expressions sometimes subsumed under the umbrella term formulaic language (11), have been attracting an increasing amount of attention in SLA circles in recent years. Many authors working in the domain of TESOL, in particular, have emphasized the need to regard collocation learning as an essential part of second language education $(3 ; 7 ; 10)$.

In fact, most multiword expressions, including collocations, are to some extent non-compositional (8). For example, run in running water does not denote the kind of rapid bipedal, self-propelled motion that 


\begin{tabular}{|c|c|c|c|c|c|c|}
\hline \multirow{4}{*}{ Impact Factor: } & ISRA (India) & $=3.117$ & SIS (USA) & $=0.912$ & ICV (Poland) & $=6.630$ \\
\hline & ISI (Dubai, UAE & $=0.829$ & РИНЦ (Russia & $=0.156$ & PIF (India) & $=1.940$ \\
\hline & GIF (Australia) & $=0.564$ & ESJI (KZ) & $=8.716$ & IBI (India) & $=4.260$ \\
\hline & JIF & $=1.500$ & SJIF (Morocce & $=5.667$ & OAJI (USA) & $=0.350$ \\
\hline
\end{tabular}

most people would think of when presented with the word run in isolation. The same applies to the use of this verb in run a business, run the risk, and run a bath. In order to see the non-compositional nature of an expression, it may be necessary to adopt the perspective of a language learner. Thus, a native speaker of English may regard catch a cold as totally compositional and so perfectly transparent, but not a learner of English who tries to make sense of the expression through reading catch as an intentional act (as in hunting, for example). So, when we say that we confine our discussion to the scenario in which learners interpret an encountered collocation as being transparent, we do not mean that their interpretation is necessarily accurate since, as just indicated, the collocation may be deceptively transparent. However, when a learner takes a collocation encountered in a text to be semantically transparent, one might be hopeful that the attention which learner would otherwise allocate to working out the meaning of the phrase can be allocated instead to the precise wording of the phrase (1).

2. Frequency occurring words in authentic contexts

A word (or word-form) may be quite frequent, but majority, or even all, of its occurrences might be in just one or two texts, in which case, although its frequency might look significant, its range might be quite small. The useful words for the learner are those words which are frequent and have a fairly wide rage that is those which occur across a wide variety of texts. Information about range can be presented in the form of statistical comparison between the occurrence of a word in one part of a corpus (e.g. just the scientific texts in the corpus) and its occurrence in the corpus as a whole. Any word that gets a differential of around 16 occurs with more or less the same frequency in the scientific texts as in the whole corpus. Any word with a lower differential is not very characteristic of scientific and learned English. Words with high differentials are characteristic of scientific and learned language (5). We may see frequent occurring words in the contexts of one specialty; petroleum engineering; sedimentary rocks, fossil fuels, petroleum, diesel, oil fields, kerosene, propane, carbohydrate, methane, hydrocarbon, liquid fuel, gaseous fuel, oxygen, overburden and etc. These technical words often occur in the context of petroleum engineering as well as mining engineering in technical English and they are considered as technical vocabulary words to acquire.

\section{Tokens and types}

Lexical variation takes as its starting point the distinction between token and type. If a text is 50 words long, it is said to contain 50 tokens, but many of these tokens may be repeated within the text and this may give us a considerable lower total of types; she promised him she would write to him and write to him she did 'there are 14 tokens but some are repeated; there are only 8 types, (she', promised, him, would, write, to, and, did,). The ratio between tokens and types for this sentence is 14:8; the difference between the two numbers is great, indicating a fairly low load of differing items. In the sentence 'as the trees grow gold and brown, then autumn has come to replace summer', we have 14 tokens and 14 types, so the vocabulary load is quite high, with no repetition. Lexical variation counts do give us a rough measure of how many new items are introduced into a text as it unfolds; this may not be the same as new words for a language learner, but it can be a useful measure in predicting the likely degree of difficulty a text might present (6.42). In the context of petroleum engineering, tokens may occur more than types;

1). Fossil Fuels hold energy stored in plant tissues by photosynthesis millions of years ago. When these ancient plants and the animals that fed on them died, they were buried in sediments, where Earth's heat and compression from the weight of overlying rock eventually turned the deposits into coal, oil, and natural gas.

2). The most common aero-geophysical maps are magnetometer maps which record the variations in the earth's magnetic field with high degree of accuracy. The optimal selection of altitude and spacing as well as choice of instrumentation is important.

According to the $\mathbf{1}^{\text {st }}$ context, there are 52 tokens and 51 types in the corpus of the petroleum engineering, and we found frequency occurred words within corpus of the petroleum engineering, they are; fossil fuel, sediments, those frequency words occur also in other written contexts of this field.

According to the $\mathbf{2}^{\text {nd }}$ context, there are 37 tokens and 35 types in the context petroleum engineering and we found that "magnetometer" frequent word also occurred in other texts of this field of.

\section{Conclusion}

In the classes of English for specific purposes, we focus on professionally-oriented context to teach and design the class, coloring it because there are some tokens and types which frequently occur not only in one text but also do in other written contexts which tell us about the subject matter and those learners need to acquire. We study collocations which modify the words related to, and vocabulary words which are tokens and types. We analyzed technical text to find out whether how many times one word occur in other sentences within specialty, and how many tokens and types does it consist of. We addressed to the discussions of scholars on the issues of collocations, tokens and types. As a result, findings were shown in the above-mentioned text examples. 


\begin{tabular}{|c|c|c|c|c|c|c|}
\hline \multirow{4}{*}{ Impact Factor: } & ISRA (India) & $=3.117$ & SIS (USA) & $=0.912$ & ICV (Poland) & $=6.630$ \\
\hline & ISI (Dubai, UAE & $=0.829$ & РИНЦ (Russi: & $=0.156$ & PIF (India) & $=1.940$ \\
\hline & GIF (Australia) & $=0.564$ & ESJI (KZ) & $=8.716$ & IBI (India) & $=4.260$ \\
\hline & JIF & $=1.500$ & SJIF (Morocec & $=5.667$ & OAJI (USA) & $=0.350$ \\
\hline
\end{tabular}

\section{References:}

1. Barcroft, J. (2002). "Semantic and structural elaboration in L2 lexical acquisition". Language Learning 52: 323-363

2. Durrant, P., \& Schmitt, N. (2009). "To what extent do native and non-native writers make use of collocations?" International Review of Applied Linguistis.

3. Lewis, M. (1993). The Lexical Approach. Hove: LTP / Boston: Thomson Heinle.

4. McCarthy, M. (1998). Spoken Language and Applied Linguistics. Cambridge: Cambridge University Press.

5. McCarthy, M. (2006). Explorations in Corpus Linguistics. Cambridge University Press. London.

6. McCarthy, M. (1990). Vocabulary. Cambridge University Press.
7. Nattinger, J. R., \& DeCarrico, J. S. (1992). Lexical Phrases and Language Teaching. Oxford: Oxford University Press.

8. Taylor, J. (2006). "Polysemy and the lexicon". In G. Kristiansen, M. Achard, R.Dirven and J. Ruiz de Mendoza Ibanez (Eds.), Cognitive Linguistics: Current applications and future perspectives. (pp.51-80). Berlin.

9. Tomasello, M. (2003). Constructing a Language: A Usage-Based Theory of Language Acquisition. London: Harvard University Press.

10. Willis, D. (1990). The Lexical Syllabus. London: Harper Collins.

11. Wray, A. (2002). Formulaic language and the lexicon. Cambridge, UK: Cambridge University Press. 